\title{
Forum:R2P@15
}

\section{Progress, Problems, and Prospects: R2P 15 Years after the World Summit}

\author{
Charles T. Hunt \\ Senior Lecturer, School of Global, Urban and Social Studies, RMIT \\ University, Melbourne, Australia \\ charles.hunt@rmit.edu.au \\ CeciliaJacob \\ Senior Lecturer, Department of International Relations, Australian National \\ University, Canberra, Australia \\ cecilia.jacob@anu.edu.au
}

\begin{abstract}
Adrian Gallagher
Associate Professor in International Relations, University of Leeds, U.K. a.gallagher@leeds.ac.uk
\end{abstract}

\begin{abstract}
This short article introduces the GR2P Forum reflecting on the Responsibility to Protect $(\mathrm{R} 2 \mathrm{P})$ doctrine 15 years after it was institutionalised at the international level through the World Summit Outcome Document. It contextualises the relevance of critical reflections on the $\mathrm{R}_{2} \mathrm{P}$ at its ${ }_{15}$ th anniversary and then lays out the aims and objectives of the Forum. It provides an overview of the different contributions, describing the perspectives of the authors and the key arguments they present.
\end{abstract}




\section{Keywords}

Responsibility to Protect - atrocity prevention - 15th anniversary of World Summit human protection

This year marks 15 years since the Responsibility to Protect $\left(\mathrm{R}_{2} \mathrm{P}\right)$ doctrine was institutionalised at the international level through the World Summit Outcome Document (WSOD). In this Forum we take the time to reflect on the development of the norm in a global reality much altered from when it was first conceived. As the contributions attest, the evolution of $\mathrm{R}_{2} \mathrm{P}$ has been impressive. It reframed what had become an entrenched debate around the legality and legitimacy of humanitarian intervention. It has been operationalised within the United Nations through strong leadership by consecutive Secretaries-General, first under Kofi Annan, then Ban Ki-moon, and now António Guterres. As of June 2020, the $\mathrm{R}_{2} \mathrm{P}$ had been referenced in 84 UN Security Council resolutions and statements. ${ }^{1}$ For many, this is evidence that the norm has gained traction since its conception. At the same time, however, limited action in response to crises in countries such as Syria, Myanmar, and Yemen highlight ongoing concerns over inconsistency and hypocrisy.

At the time of writing (July 2020) there are extremely concerning reports of atrocity crimes in many countries. For instance, despite the International Court of Justice ruling in relation to Myanmar earlier this year, new evidence from Amnesty International shows air strikes being carried out against civilians. ${ }^{2}$ Meanwhile the United Kingdom has agreed to resume arms sales to Saudi Arabia despite ongoing concerns over their use for war crimes in Yemen. ${ }^{3}$ These are just two examples among many more and highlight key themes that this journal has published on in the last year with special issues on $\mathrm{R}_{2} \mathrm{P}$ and the Arms Trade and $\mathrm{R}_{2} \mathrm{P}$ and Myanmar. ${ }^{4}$ In many ways $\mathrm{R}_{2} \mathrm{P}$ scholars continue to

1 GCR2P, 'R2P References in UN Security Council Resolutions and Presidential Statements', 17 June 2020, https://www.globalr2p.org/resources/un-security-council-resolutions-andpresidential-statements-referencing-r2p/, accessed 6 August 2020.

2 Amnesty International UK, 'Myanmar: Civilians and Children Killed in Military Airstrikes as Conflict Intensifies', 3 July 2020, https://www.amnesty.org.uk/press-releases/myanmarcivilians-and-children-killed-military-airstrikes-conflict-intensifies, accessed 6 August 2020.

3 Dan Sabbagh, 'Britain to Resume Sale of Arms to Saudi Arabia Despite Yemen Fears', The Guardian, 7 July 2020, https://www.theguardian.com/world/2020/jul/o7/britain-to-resume -sale-of-arms-to-saudi-arabia-despite-yemen-fears, accessed 6 August 2020.

4 'Special Issue: the Rohingya Crisis and Implications for Myanmar's Peace Process', Global Responsibility to Protect, 12(1) (2020). For the Arms Trade, see Global Responsibility to Protect, $12(2)(2020)$. 
critically reassess the $\mathrm{R}_{2} \mathrm{P}$ and the role of key actors in governments and civil society around the world.

With this in mind, the 15th anniversary is an apt moment to reflect on R2P's progress, problems and prospects. This Forum brings together a range of practitioners and policymakers - including former government ministers and officials, senior UN advisers, research and advocacy organisations - who have been instrumental in the emergence, development, and implementation of the $\mathrm{R}_{2} \mathrm{P}$. Each contributor evaluates the progress of $\mathrm{R}_{2} \mathrm{P}$ in relation to their unique experiences and insights and offers advice and recommendations for advancing the next phase of $\mathrm{R}_{2} \mathrm{P}$ institutionalisation, promotion and operationalisation.

In his contribution, Gareth Evans - Co-Chair, International Commission on Intervention \& State Sovereignty and former Australian Foreign Minister takes stock of the extent to which $\mathrm{R}_{2} \mathrm{P}$ has both met and fallen short of the dreams of its founders. He argues that $\mathrm{R}_{2} \mathrm{P}$ 's record has been disappointing as an effective counter-force to atrocity crimes already under way. But as an institutional catalyst and preventive mechanism it has been generally successful, and as a normative force it has become 'a new norm of international behaviour which, overwhelmingly, states feel ashamed to violate, compelled to observe, or at least embarrassed to ignore'.

Savita Pawnday and Jaclyn Streitfeld-Hall - Deputy Executive Director and Publications Director from the Global Center for $\mathrm{R}_{2} \mathrm{P}$ - argue that the $\mathrm{R}_{2} \mathrm{P}$ has helped in 'raising our collective consciousness about atrocity situations' and that this has 'informed the decision to respond, even when those responding have not necessarily waved the flag of $\mathrm{R}_{2} \mathrm{P}$ '. They further suggest that examples such as the Gambia - which has averted risks of atrocities at home as well as shown leadership in seeking accountability for them extraterritorially - should 'give us cause for hope'.

Co-Director and Research Director at the European Centre for $\mathrm{R}_{2} \mathrm{P}$, Cristina Stefan and Edward Newman, argue that the European Union (EU) has been an often overlooked but important actor in the story of $\mathrm{R}_{2} \mathrm{P}$. They argue that sustaining this commitment into the future will require that $\mathrm{R}_{2} \mathrm{P}$ is embraced 'not only by EU officials, but also by political leaders in member states, and the ability of the EU to bring better policy coherence across the broad range of programmes and activities that could better serve the $\mathrm{R}_{2} \mathrm{P}$ agenda'.

Chief Prosecutor of the International Criminal Court (ICC), Fatou Bensou$\mathrm{da}$, recounts progress and convergence of the ICC and $\mathrm{R}_{2} \mathrm{P}$ norms against the backdrop of increasing pressures on multilateral institutions. She argues that the Court's efforts to end impunity for mass atrocity crimes are mutually reinforcing with $\mathrm{R}_{2} \mathrm{P}$ and that both help to 'cultivate an ethos of accountability, 
with a view to protecting citizenry and preventing future crimes'. She argues that ratification of the Rome Statute by more countries and further domestication of its provisions through national legislation is the essential 'first line of defence against atrocity crimes' and calls on parties to 'vehemently reject any effort to undermine the Court's independence and crucial work'. Bensouda concludes with a warning against becoming 'complacent' and emphasises the importance of a 'consistent, principled and carefully calibrated approach' by actors seeking to prevent and halt atrocities.

Victoria Holt - Vice President, Stimson Center and former US Deputy Assistant Secretary of State - reflects on her time as a policymaker in the Obama administration with particular reference to the interagency Atrocity Prevention Board that convened US departments and agencies to improve tools and country-specific strategies. She argues that the US government got plenty right that contributed to building preparedness for preventing and responding to mass killing. However, she also identifies several areas where they missed the target, including the pursuit of peace deals that have failed to stop the killing in places like South Sudan. Holt also discusses the perennial challenge of turning early warning into early action. She concludes with a clarion call that a wide range of stakeholders should 'elevate atrocity prevention again as a core moral responsibility' and use the failures as motivation to 'recognise anew the need to prevent extreme violence'.

Finally, the first ever Special Adviser to the UN Secretary-General on the $\mathrm{R}_{2} \mathrm{P}$ and current Columbia University Professor, Edward Luck, compares the $\mathrm{R}_{2} \mathrm{P}$ to a teenager, suggesting that like other adolescents, [it] is viewed with an uneasy mix of expectations and trepidations'. He describes how the $\mathrm{R}_{2} \mathrm{P}$ contributed to saving lives of Ivoirians, Kenyans, Guineans, and Kyrgyzstanis while failing to mobilise adequate responses to similar needs of Sri Lankans and Syrians. Based on his experience of decision-making at the coalface, Luck concludes by advocating for greater 'individual responsibility' on the part of those who can make the difference between life-saving responses or fatal inaction. 